\title{
THE "PUBLIC PURPOSE" OF MUNICIPAL FINANCING FOR INDUSTRIAL DEVELOPMENT*
}

The laws of twelve states enable local governments to purchase sites and erect plants for private industry to induce them to move into the locality. Mississippi, in 1936, was the first state to adopt such laws. ${ }^{1}$ Eleven states have done so since $1950 .^{2}$

The number of projects within such states is growing. Pursuant to Tennessee's 1955 Bond Act, for example, one project was initiated in 1957, three in 1958 , seven in 1959 , and twenty-one in $1960 .^{3}$ Municipal financing legislation has sometimes occurred in periods of economic decline. The first of such legislation was enacted in Mississippi during, and presumably in response to, the depression. In Vermont, Tennessee, and Arkansas the legislation came after a decline in industrial employment, a decline preceded by growth years. ${ }^{4}$ Mississippi's legislation is called the Balance Agriculture With Industry Plan

*Wayland v. Snapp, 334 S.W.2d 633 (Ark. 1960).

1. Mirs. Code ANs. $\$ \$ 8936$ to $8936-24$ (1957).

2. Ala. Code tit. 37, $\$ 511$ (20 to 32) (1959); Ark. Consr. amend. 49 ; Ark. Laws 1960, 1st Ex. Sess., No. 9; Ild. ANN. Stat. ch. 24, § 1211-24 (Smith-Hurd 1960); Kx. Rev. Stat. § 103.200-.2S0 (1959) ; LA. Const. art. XIV, § 14(b) (2) ; Md. Acts 1953, ch. 662, § 103 (applicable to Frostburg, Md., only) ; Mo. Const. amend. 4 (approved by the electorate Nov. \&, 1960); NEB. REv. Stat. § 18-1601 to -1613 (1954) (declared unconstitutional in State $e x$ rel. Beck v. City of York, 164 Neb. 223, 82 N.W.2d 269 (1956); Neb. Const. art. 15, $\$ 16$ (approved by the electorate No. 8, 1960); N.M. Stat. Ann. \$ 14-41-31 to -43 (Supp. 1959); TeNN. Code ANN. \$ 6-2901 to -2916 (Supp. 1960); VT. StAт. AnN. tit. 24, §§ 2701 to -14 (1959).

3. Letter From Harry F. McClure to the Yale Law Journal, Jan. 12, 1961, on file in Yale Law Library. The volume of Mississippi BAWI bond issues have risen from $\$ 4,689,000$ in 1957 to $\$ 18,164,500$ in 1960 . Letters From William Keith to the Yale Law Journal, Jan. 17, 1961, on file in the Yale Law Library. Although New Mexico's statute was adopted in 1955, her communities did not develop projects until 1960. The Wall Street Journal, Oct. 11, 1960, p. 1, col. 1.

4. Tennessee and Vermont enacted their laws in 1955, Arkansas a constitutional amendment in 1958.

\begin{tabular}{lrrrrrrr} 
& \multicolumn{8}{c}{ ManUfacturing } & EMPLOYEES IN THOUSANDS \\
$Y \mathfrak{e a r}$ & 1951 & 1952 & 1953 & 1954 & 1955 & 1956 & 1957 \\
Tennessee & 264.6 & 274.3 & 291.4 & 273.7 & - & - & - \\
Vermont & 38.7 & 38.3 & 40.5 & 36.8 & - & - & - \\
Arkansas & 82.5 & 80.4 & 82.7 & 80.8 & 85.7 & 90.3 & 86.5
\end{tabular}

Source: U.S. Dept. of Labor, 76-81 Monthly Labor Review, Table A-7 (1951-1958).

Of course, many factors in addition to employment should be correlated with such legislation. See The Arkansas Gazette, Jan. 15, 1960, p. 1F, col. 8; The New York Times, Jan. 9, 1961, p. 124, col. 4, for discussion of the relationship between the Arkansas industrial decline and the 1951 Little Rock school segregation crisis. The New Mexico legislation has been attributed to a dramatic rise ( $40 \%$ since 1950 ) in population and to industrial instability due to the heavy reliance of its industries on government contracts. Wall Street Journal, Oct. 11, 1960, p. 1, col. 1 . 
(The BAWI Plan), a title which suggests a further explanation for such laws. In addition, some states may adopt municipal financing legislation as a protective measure against raids upon its existing industries by other states.

Under plans developed pursuant to these laws, the local government pays for the site and plant through the issuance of bonds and subsequently retires the bonds with rental payments from the new industry. Municipalities generally plan to retire bonds in twenty to twenty-five years. ${ }^{6}$ When the manufacturer has paid sufficient rent to enable the municipality to retire the bonds, the industry may exercise an option to buy the facility, ${ }^{7}$ or continue to lease at a nominal rental, ${ }^{8}$ depending on the requirements of the state enabling legislation or the industry's agreement with the municipality. Such plans enable a manufacturer to expand or relocate without a heavy investment of its own capital. In addition, because the interest on municipal securities is exempt from federal income tax, ${ }^{9}$ and perhaps state taxes, ${ }^{10}$ municipalities generally borrow at lower interest rates than private borrowers and this saving is usually passed to the industry. The plant site may be exempt from local ad valorem taxes. ${ }^{11}$

5. This may be the reason for the Illinois law, enacted in 1951. In 1950, e.g., four concerns with Illinois plants completed plans to expand or relocate in Mississippi, pursuant to the BAWI Plan. But six Illinois concerns erected municipally financed projects in Mississippi in 1960. Mississippi Agricultural and Industrial Board Sumarary of Mirssissippi BaWI Plants, 4 Thomas' Register of Amerrcan Manufacturers (1957); cf. The New Haven Register, Feb. 8, 1961, p. 14, col. 1 (proposal by state senator to require industries to give employees notice before leaving community). For a discussion of financing of industry schemes as a weapon for competition for new industry among states and communities, see The Arkansas Gazette, Jan. 15, 1961, p. 1f, col. 2.

Various unique local events may precipitate municipal financing legislation. Louisiana's legislation, a constitutional amendment, is often thought to be the result of a decline in wholesale milk prices. See Miller v. Police Jury, 226 La. 8, 19, 74 So. 2d 394, 398 (1954) ; Note, Municipal Inducements to Private Industry, 40 MINN. L. Rev. 681, 686 (1956).

6. See summary of Mississippi BAWI Plants, Mississippi Agricultural and IndusTRIAL BoARD op. cit. supra note 5. The time may be imposed by statute, e.g., KY. REv. STAT. \$ 103.200 (1959) (25 years), although often the period allozved by statute may be longer, $c, g$., TenN. Code ANn. § 6-2904 (Supp. 1960) (40 years).

7. See, e.g., Village of Deming v. Hosdreg Co., 62 N.M. 18, 36-37, 303 P.2d 920, 932 (1956) ; Darnell v. County of Montgomery, 202 Tenn. 560, 564-65, 308 S.W.2d 373, 374 (1957) ; State v. Town of No. Miami, 59 So.2d 779 (Fla. 1952) ; LA. Const. art. 14(ba) (a); Ill. Stat. Ann. ch. 24, § 1214(6) (Smith-Hurd 1960) ; Vt. Stat. Ann. tit. 24, § 2703(6) (1959).

8. E.g., Newberry v. City of Andalusia, 257 Ala. 49, 57 So.2d 629 (1952) ; Faulconer v. City of Danville, $313 \mathrm{Ky} .468,232$ S.W.2d 80 (1950). All state enabling laws, see note 2 supra, permit local governments to lease the facilities.

9. INT. REv. Code of 1954, § 103(a) (1).

10. E.g., Alabama exempts income of bonds and lease agreements made pursuant thereto from all state and local taxes, Ala. Code Ann. tit. 37, \$ 511(30) (1959); Vt. Stat. Ann. tit. 24, \& 2711 (1959), and Miss. CoDE ANN. § 8936-17 (1957), grant the exemption for bonds except from inheritance, estate, and transfer taxes.

11. See e.g., Miss. Code Ann. \$ 8936-21 (1957). But see Neb. Const. art. 15, § 16 (exemptions expressly disallowed). In the absence of express provision, courts differ. Compare Wayland v. Snapp, 334 S.W.2d 633, 641 (Ark. 1960), with Village of Deming v. Hosdreg Co., 62 N.M. 18, 303 P.2d 920 (1956). 
Finally, the rental arrangement with the municipality offers the manufacturer the federal tax advantages of a sale-and-leaseback plan. ${ }^{12}$

Municipal financing legislation and projects have frequently been questioned in taxpayer suits, on the ground that they violate state constitutional provisions prohibiting the use of public funds or credit for purposes which are not "public." 13 Often, such suits are brought by industrialists and others who seek prior judicial approval of a project. ${ }^{14}$ In most cases, the projects and legislation have been upheld. ${ }^{15}$ The grounds for deciding such cases, however, are seldom articulated clearly. Statements concerning the impact of the project on the community, such as the alleviation of unemployment, are frequently made. ${ }^{16}$ The project may have other effects upon the community, however, and the opinions do not indicate what relevance these other effects may have on the issue of whether the purpose served by the project is "public" or "private." Nor do the opinions indicate the extent to which the "public purpose" and "credit" clauses authorize judicial review of legislative conclusions about the probable effects of the project. The following analysis is a tentative attempt to develop a more systematic and inclusive set of criteria capable of identifying and integrating all these factors in a single process of decision.

The decision of the Arkansas Supreme Court in Wayland v. Snapp ${ }^{17}$ illustratrates judicial response to municipally financed industrial projects. The city of Batesville, Arkansas, and Independence County, in which Batesville is located, undertook to finance the construction of a new plant for the Seiberling Rubber Company of Barberton, Ohio. The county proposed to finance its share of the project through the issuance of $\$ 500,000$ in general obligation bonds, under authority granted to local governments by Amendment 49 of the Arkansas constitution. Adopted in 1958, the amendment provides that: "Any city ... and any county ... may issue ... bonds ... for the purpose of securing and developing industry within or near the ... municipality . . or . . . county." The county

12. When the lessee buys or rents at a nominal price after the bond issue has been retired, he has in effect amortized the cost of the project, including cost of land, in rent payments which generally are deductible. INT. REv. CODE of 1954, § 162(a) (3). But see Jones, Federal Income Tax Deductions of BAWI Leasehold Payments, 30 Miss. L.J. 10 (1958) (recent revenue ruling, limits a lessee's rent deductibility).

13. The two provisions most commonly invoked, the "credit clause" and the "public purpose" doctrine, are discussed at notes $22-43$ infra.

14. See, e.g., Holly v. City of Elizabethton, 193 Tenn. 46, 55-56, 241 S.W.2d 1001, 1006 (1951) ; Village of Deming v. Hosdreg Co., 62 N.M., 18, 303 P.2d 920 (1956).

15. Newberry v. City on Andalusia, 257 Ala. 49, 57 So. 2d 629 (1952); Wayland v. Snapp, 334 S.W.2d 633) (Ark. 1960) ; Dycke v. City of London, 288 S.W.2d 648 (1956); Miller v. Police Jury, 226 La. 8, 74 So. 2d 394 (1954) ; City of Frostburg v. Jenkins, 215 Md. 9, 136 A.2d 852 (1957) ; Village of Deming v. Hosdreg Co., 62 N.M. 18, 303 P.2d 920 (1956) ; Holly v. City of Elizabethton, 193 Tenn. 46, 241 S.W.2d 1001 (1951); McConnell v. City of Lebanon, 203 Tenn. 498, 314 S.W.2d 12 (1958). Contra, State v. Town of No. Miami, 59 So. 2d 779, (Fla. 1952); State ex rel. Beck v. City of York, 164 Neb. 223, 82 N.W.2d 269 (1957).

16. See text at notes 51-59 infra and accompanying text.

17. 334 S.W.2d 633 (Ark. 1960). 
intended to levy a five-mill property tax authorized by Amendment 49 if the lease money from Seiberling proved insufficient to retire its bonds. The city of Batesville planned to issue $\$ 1,000,000$ in revenue bonds pursuant to Act 9 , a statute adopted by the Arkansas legislature in 1960. The revenue bonds were to be retired by lease payments from Seiberling, and were secured by a mortgage on the property and by the city's pledge of its surplus utility revenues if further security became necessary.

Two of the major challenges leveled against the plan were: first, the project was a local government loan to a private corporation, contrary to the Arkansas constitution's credit clause, which states : "No county, city ... shall . . . obtain or appropriate money for, or loan its credit to, any [private] corporation, association, institution, or individual"; ${ }^{18}$ second, Act 9 authorizes municipalities and counties to issue bonds for purposes that are not public, contrary to the "public purpose" doctrine of the Arkansas constitution. ${ }^{10}$

The project was upheld by the Arkansas court. Since the Independence County general obligation bonds had been issued pursuant to Amendment 49, the court assumed that the taxpayer had not intended to challenge them as violative of the credit clause of the state constitution. ${ }^{20}$ The revenue bonds might have been upheld against the credit clause attack for the same reason, since Amendment 49 does not expressly limit its grant of authority to the issuance of general obligation bonds. The court, however, chose to uphold the issuance of the revenue bonds by involking the doctrine that revenue bonds do not violate a credit clause because they are retired through lease revenues of the project, not out of tax funds. It assumed the purpose of the credit clause to be the protection of taxpayers against taxes levied to retire the bonds, and concluded that "... revenue bonds ... can never be a burden on the taxpayers ...." 21

18. Although the Arkansas credit clause does not contain the word "private," it has been held that the credit clause does not prohibit aid to public corporations, but only to "private enterprises, or a business corporation or association ...." City of Paris v. Street Improvement Dist. No. 2, 206 Ark. 926, 929, 175 S.W.2d 199, 200 (1943). ARK. CoNsT. art. $12, \S 5$, the credit clause, is entitled: "Political subdivision not to become stockholders in or lend credit to private corporations."

19. 334 S.W.2d at 637.

The taxpayer attacked the project on six additional grounds 334 S.W.2d at 636. 1) The county lacked the authority under amendment 49 to make available the proceeds of funds to construct a facility that the city of Batesville, rather than the county, would own. 2) While cities and counties cooperating in the securing of industries are required by Arkansas law to form compacts, no such agreements were entered here. 3) The pledge of surplus utiliity revenues to the payment of the revenue bonds violated the Arkansas constitution's debt limit. 4) The granting of a foreclosable mortgage lien and the right to appointment of a receiver were contrary to Arkansas law. 5) The representation and proposed action to implement the representation that the facilities would be exempt from ad valorem taxation were contrary to Arkansas law. 6) The method of financing, constructing, leasing, taxing, and applying funds and lease rentals was contrary to the laws and constitution of Arkansas.

20. Ibid.

21. Id at 637.

General obligation bonds involve the community's taxing power more directly because the community pledges its full faith and credit. See, e.g., TENN. Code ANn. § 6-2911 (Supp. 
While most courts have held that the issuance of revenue bonds does not fall within the credit clause regulation of extensions of credit, ${ }^{22}$ one court has found to the contrary. Apparently reading the prohibition against appropriations or loans of credit as a prohibition against all governmental activity (presumably because any activity involves some risk to public monies), the Nebraska Supreme Court has reasoned that the issuance of revenue bonds may create obligations such as executing leases, fixing rents, taking chattel mortgages, procuring insurance coverage, and assuming the added tax burdens of increased community services if the new industry failed to pay its own way. ${ }^{23}$ Also, it has been pointed out that if there were a default on the bonds, the city's reputation as a borrower might be damaged, with the result of higher interest rates, and hence higher tax rates, when the municipality seeks to issue securities in the future. ${ }^{24}$ Furthermore, if a city contracts to purchase a site and plant for the use of an incoming manufacturer, and he decides not to use the purchased facility, the city may be liable on its contract to purchase. ${ }^{25}$

But even if the statute were only intended to protect against liability arising from default, there are numerous ways in which a municipality may become directly liable to the revenue bond holders. If the municipality were grossly negligent in the issuance of the bonds, because it was clearly impossible for the project to succeed, the municipality might be held in breach of an implied covenant of good faith. ${ }^{26}$ Misrepresentation, implied covenant or warranty, and breach of trust are additional theories through which the general taxing power of the municipality might be reached. ${ }^{27}$ Even under the Wayland court's narrow interpretation, therefore, credit clause restrictions should apply to revenue bonds as well as general obligation bonds, requiring courts to inquire into the "public" nature of any activity financed by municipal bonds.

1960) : “... any municipality shall have the power ... to pledge ... the full faith and credit and unlimited taxing power of the municipality ... on such bonds . ..." See FordHAM, Local Government Law 526 (1949).

22. See, c.g., Snodgrass v. City of Pocahontas, 189 Ark. 819, 75 S.W.2d 223 (1934); In re Opinion of the Justices, 256 Ala. 162, 53 So. $2 d 840$ (1951); Newberry v. City of Andalusia, 257 Ala. 49, 57 So. 2d 629 (1952); Faulconer v. City of Danville, $313 \mathrm{Ky} .468$, 232 S.W.2d S0 (1950); Village of Deming v. Hosdreg Co., 62 N.M. 18, 303 P.2d 920 (1956) ; Holly v. City of Elizabethton, 193 Tenn. 46, 241 S.W.2d 1001 (1951).

23. State $c x$ rel. Beck v. City of York, 164 Neb. 223, 82 N.W.2d 269 (1957). See also State v. Town of North Miami, 59 So. 2d 779, 787 (Fla. 1952) (revenue bonds for private industrial development violated credit clause without discussion whether revenue bonds are loans of credit).

24. See Virtue, The Public Use of Private Capital: A Discussion of Problems Related to Mfunicipal Bond Financing, 35 VA. L. Rev. 285, 294-95 (1949); Note, 66 Harv. L. Rev. $898,902,908$ (1953).

25. See Springfield Tobacco Redryers Corp. v. City of Springfield, 41 Tenn. App. 254, 293 S.W.2d 189 (1956). Municipal liability for negligent destruction of the security is also possible, see Fordham, Reveme Bond Sanctions, 42 Colum. L. REv. 395, 412 (1942).

26. See Armstrong, "Municipal Inducements"-The New Mexico Commercial and Industrial Project Revenue Bond Act, 48 CaLIF. L. Rev. 58, 62 n.19 (1960).

27. See Fordham, supra note 24, at 409-11. 
After deciding that revenue bonds were not loans of credit, the Wayland court went on to consider, as a separate issue, whether the bond project constituted a "public purpose." The "public purpose" doctrine, generally derived from state constitutional provisions, is similar to the credit clause;20 it seems to be regarded as being of broader applicability, restricting the use of any governmental resources to activities which are "public." 30

The Wayland court's discussion of the public purpose issue at first gives no evidence of the criteria applied. In response to the "credit clause" challenge (i.e., that the bonds were to be issued for the benefit of a private corporation), the court asserted that "the main benefits [of the project] are those to be derived by the people of Batesville and Independence County . . .." 31 Unfortunately, the court did not reveal what factors made the project a benefit to the

28. See H.R. REP. No. 2543, 83d Cong., $2 d$ Sess. 33 (1954) (Municipal securities should be exempt because they serve "proper governmental functions.").

29. State constitutions frequently contain express prohibitions on the use of credit, or "credit clauses." See generally Note, 59 CoLuar. L. REv. 618, 620-21 (1959) (collecting provisions). The general "public purpose" doctrine pertaining to use of public monies is drawn from explicit prohibitions, e.g., S. C. CoNsr. art. VIII, \$\$ 3, 6; see also City of Phoenix v. Michael, 61 Ariz. 238, 148 P.2d 353 (1944) (derived from constitutional credit clause); State $e x$ rel. Beck v. City of York, 164 Neb. 223, 82 N.W.2d 269 (1957) (same), from general due process clauses, e.g., AlA. Const., art. $1, \S 6$, and sometimes from "organic" law, e.g., State v. Town of No. Miami, 59 So. 2d 779, 785 (Fla. 1952), or common law, e.g., McConnell v. City of Lebanon, 203 Tenn. 498, 509-11, 314 S.W.2d 12, 17 (1958).

The public purpose doctrine has also been held a requirement of the fourteenth amendment. Carmichael v. Southern Coal Co., 301 U.S. 495, 514 (1937). The role of federal courts is limited, however.

[W] hat was or was not a public use was a question concerning which local authority, legislative and judicial, had especial means of securing information to enable them to form a judgment; and particularly, that the judgment of the highest court of the State declaring a given use to be public in its nature, would be accepted by this court unless clearly unfounded.

Green v. Frazier, 253 U.S. 233, 242 (1919); see Albritton v. City of Winona, 181 Miss. 75, 178 So. 799, appeal dismissed for want of a substantial federal question, 303 U.S. 627 (1938). Quaere the role of the Supreme Court if a state court, having declared a financing statutc to violate public purpose, declares a subsequent constitutional amendment authorizing municipal financing to violate the fourteenth amendment? See State ex rel. Beck v. City of York, supra, (perhaps overruled by NeB. Const. art. XV, § 16, approved Nov. 8, 1960).

30. The court's finding that the project served a public purpose made its earlier discussion of the credit clause unnecessary. The credit clause, prohibiting expenditures for private interests, is subsumed in the public purpose doctrine, which is directed to all exercises of governmental power, not just expenditures. 2 MCQuilim, Municipal CorforaTrons 647 ( $3 \mathrm{~d}$ ed. 1949). Curiously, two states derive the public purpose doctrine from the credit clause. City of Phoenix v. Michael, 61 Ariz. 238, 148 P.2d 353 (1944); State ex rel. Beck v. City of York, 164 Neb. 223, 82 N.W.2d 269 (1957).

31. 334 S.W. at 637.

32. See Embury v. Conner, 3 Comst. 511, 516 (N.Y. 1850). In the context of early eminent domain cases, primarily for road building and public parks, the "use" requirement was not as meaningless as it is presently. See Comment, What Coustitutes a Public Use?, 23 Albany L. Rev. 386 (1959). 
public. The same difficulties inhere in all judicial attempts to equate, and thus to define, public purpose with another equally vague, itself undefined, term such as "use," 32 "advantage," 33 and "utility." 34

The subsequent discussion of the public purpose doctrine, though also imprecise, is more illuminating. The court presumed the taxpayer to be challenging "the securing or developing of industry" on public purpose grounds, and explained: ". . . the courts seem to be in agreement that such activity constitutes a public purpose." 35 In support, the court quoted from the 1938 Mississippi Supreme Court case which passed upon Mississippi's financing of industry plan: "The care of the poor, the relief of unemployment, and the promotion of agriculture and industry are undoubtedly proper governmental purposes, are so recognized everywhere and by all." ${ }^{36}$ It is most likely that the Wayland court regarded the "activity" that served a public purpose to be broader than unemployment relief alone. Batesville's attempt to secure and develop a new industry might in itself have been regarded as sufficient public purpose. Four state cases were cited for the proposition that the "activity" constitutes a public purpose everywhere, and the general objective of industrial development is their main shared characteristic. Their specific goals vary: the relief of unemployment and the balancing of agriculture with industry, ${ }^{37}$ the processing of milk to raise local milk prices, ${ }^{38}$ the processing of pine stumps to provide a local sales outlet for them, ${ }^{39}$ and the relief of unemployment. ${ }^{40}$ These four decisions are based upon the expectation that through municipal financing of new industry the general economic position of the community will be advanced. Typical is the statement that the purpose of the plan was "to relieve an economic condition affecting the welfare of the people of the entire parish." 41

Although the several factors mentioned by the Wayland court and other authorities seem to be used as criteria for determining whether a purpose is "public," the opinions do not give a satisfactory statement of the ultimate question to be answered by applying these criteria. The distinction between purposes "public" and "private" is seldom articulated. A transfer of public funds to an individual to spend as he pleases is commonly regarded as serving a "private" interest. Transferring public funds to an individual in return for goods or ser-

33. See, e.g., Village of Deming v. Hosdreg Co., 62 N.M. 18, 35, 303 P.2d 920, 931 (1956). It can be implied from the opinion that the referent of "advantage" was the relief of unemployment, inspiration of new hope, and promotion of industry, but the court did not make that equation explicit.

34. See, c.g., Cleveland, C.C. \& St. L. Ry. v. Polecat Drainage Dist., 213 I1l. 83, 85, 72 N.E. 684, 685 (1904) (public use equated with usefulness, utility, advantage or benefit).

35. 334 S.W.2d at 637 .

36. Albritton v. City of Winona, 181 Miss. 75, 97-98, 178 So. 799, 804 (1938), cited with emphasis added at 334 S.W.2d at 638 .

37. Albritton v. City of Winona, 181 Miss. 75,178 So. 799 (1938).

38. Miller v. Police Jury, 226 La. 8, 74 So. 2d 394 (1954).

39. Newberry v. City of Andalusia, 257 Ala. 49, 57 So. 2d 629 (1952).

40. Dyche v. City of London, 2S8 S.W.2d 648 (Ky. 1956).

41. Miller v. Police Jury, 226 La. 8, 19, 74 So. $2 d$ 394, 398 (1954). 
vices for the municipality is usually viewed as serving a "public" interest. Clearly, the differentiation between the two transfers is not that a private individual gains, for suppliers to local governments are also expected to profit. ${ }^{42}$ It is less apparent but equally true that the distinction does not rest on the fact that the community, or the public, receives nothing in return for the "dole." The community is, after all, nothing more than a group of individuals, and at least one individual, the donee, profits from an outright gift. The relevant distinction seems to be that the community does not receive value proportionate to the value it gives.

It is presumably this net gain to the community that courts have in mind when they speak of "public benefit" or of relieving conditions which affect "the welfare of the people of the entire parish." 43 But if net gain to the community is at issue, it would seem irrational not to consider all the effects which a project may have. A proper inquiry would include calculations of the economic need for municipal activity, the likely success of the project, its probable effect on existing industry, the consequences for local labor conditions, and the impact on community commerce. Even then, however, net gain cannot be meaningfully calculated unless the impact of the project on other community values such as enlightenment, health, and allocation of decision-making power are also considered. In other words, the relevant inquiry would seem to be whether the proposed project will augment the community's total value position.

The question remains as to how far a court should inquire into these various factors when making a public purpose inquiry, and to what extent it should defer to the conclusions of the legislative and executive officials who have initiated the project? ${ }^{44}$ The nature of the decision and the relative capabilities of the institutions involved are relevant. An estimate of net gain or loss to the community requires a consideration of the multitude of different values which may be affected. The impact of the project on each community value is necessarily a matter of prediction, the uncertainty of which will vary from case to case. Moreover, the project's impact on each value has to be weighed against the possible contrary impact on other values, a decision which involves an additional weighing of the relative importance of each value affected. It becomes evident, therefore, that the most competent decision maker is the one which possesses at least these two characteristics: (1) the capacity to make the most

42. See e.g., Johnston v. Kapp, 103 Cal. App. 2d 202, 229 P.2d 414 (Dist. Ct. App. 1951) (pay raise during existing contract for public employee did not violate credit clause because public received the benefit of his services).

43. For apparent recognition of net gain as the criteria for public benefit, see Village of Deming v. Hosdreg Co., 62 N.M. 18, 35, 303 P.2d 920, 930 (1956) ("if the overall picture shows a comfortable balance of advantages over disadvantages to the many").

44. This question need not be viewed as something apart from an inquiry into the merits of the project. The extent to which a court remakes the decision of the legislative and executive officials who have initiated the project will have an effect upon the distribution of decision-making power within the community, and this is one value in the totality of community values which must be weighed. 
expert analysis, and (2) the ability best to determine what values are most important to the community in a given situation.

Consideration of these two characteristics may lead courts to confine their review under the "public purpose" doctrine as narrowly as possible. The court may subscribe to the view that the hierarchy of community values is best determined by the will of the electorate, and may believe that legislative decisions are more representative of popular opinion because individuals have greater access to their legislative representatives. Also, courts may believe that legislative and administrative bodies have more experience and greater resources for "expert" assistance. In their search for relevant information, such institutions are not limited by the restrictions of a judicial proceeding. On the other hand, the accuracy of these assumptions may be questionable in the context of municipal financing of industry. In considering the policy of deference to public opinion, it may be relevant to inquire whether the vigorous promotion of such projects by organized national and local business interests ${ }^{45}$ does not give local officials a one-sided view of public opinion concerning the project. Moreover, assumptions concerning the greater access of varied private interests to legislative decision makers may be questioned where statutes do not provide for local hearings. ${ }^{46}$ Even popular referendum may not be a genuine indication of public opinion, for the local electorate may lack adequate information about the project's consequences on the community. In addition, state court judges are often elected, so that they are not immune to electoral sanction when their decisions are contrary to public expectations. The "expertise" of legislators in the municipal financing situation can also be doubted in many cases. Only two states require state administrative agency approval of a project, and even these two agencies have never formally appraised the impact of new projects on communities. ${ }^{47}$ Moreover, most of the

45. Apparently, only the United States Chamber of Commerce has prepared an appraisal, see note 59 infra, of the impacts of new industry on communities. See Letter From William Keith, note 5 supra. The Arkansas Gazette, Oct. 26, 1960, p. 1B, col. 2, attributes the Batesville project to the efforts of the Batesville Chamber of Commerce and the Missouri Pacific Railroad.

46. See, e.g., Ill. ANr. Stat. ch. 24, § 1215 (Smith-Hurd 1960) : "The construction, acquisition, reconstruction, improvement, betterment or extension of any industrial buildings . . . and bonds may be authorized ... to provide funds for such . . . purposes . . . by resolution ... of the governing body which may be adopted at the same meeting at which they are introduced by a majority of all the members thereof . . . and shall take effect immediately upon adoption." Only the bonds must be approved.

47. The Mississippi Agricultural and Industrial Board must issue a certificate of public conyenience and necessity. Miss. Code ANN. § 8936-07 (Supp. 1958). The Tennessee Industrial and Agricultural Development Commission must issue a certificate of public purpose and necessity. TENN. CODE ANN. \& 6-2905 (Supp. 1960). The activities of the agencies seem largely promotional and no studies of the impacts of the projects have been made by either agency. See Letters From William E. Keith, Information Department, Mississippi Agricultural and Industrial Board, Jan. 17, 1961, and Harry F. McClure, Division of Industrial Development, Tennessee Department of Conservation and Commerce, Jan. 12, 1961, to the Yale Law Journal on file in Yale Law Library. 
projects are initiated in communities of less than $10,000.48$ Such towns are often unable to employ city planners, industrial administrators, and other "experts." 40 If this view of municipal financing projects is correct, it may be proper for courts to give less weight to the reasons for judicial restraint when weighing the criteria relevant to a "public purpose" determination.

But even if a court concludes that legislative decisions in this area deserve the greatest judicial deference, a further question is raised by asking how the court can give effect to such deference. A common answer of federal courts in reviewing "social and economic" legislation is to say that the legislation will be upheld if a "rational nexus" is found between the means adopted and an approved end,";0 or if the statute is not "arbitrary." These words imply a test in which the court makes some judgment about the probability that the legislation will accomplish what it proposes to accomplish. If it is clearly impossible to achieve the end by the means adopted, the statute is arbitrary. The crucial question is to what extent the court will receive evidence on the issue of rational nexus. The absence of discussion of this point in the Wayland opinion suggests that the court accepted the project's reasonability on the basis of a general judicially noticed belief that industrialization usually results in economic betterment. It might be argued that such conclusions are based too much on supposition, and that a more rational approach to the problem would be to examine each possible consequence of the project in detail. Such inquiry need not diminish the court's deferential attitude for it may still choose to defer whenever, after prolonged investigation, it concludes that there is a rational possibility of gain to the community. In addition to being a more rational approach, the detailed inquiry would also give parties an opportunity to show in specific cases that the court's intimation is wrong.

These problems of decision making in the area of industrial development will more clearly be presented by detailed attention to the kind of analysis which may be called for, and to the wide range of values which are affected by a new project. While immediate attention has been given to what courts might do, the following analysis would be applicable to the decision of any official concerned with initiating and prescribing a given project.

48. Populations of $\mathbf{5 5}$ communities establishing projects in 1960 in Mississippi, Tennesseesee, Arkansas, and New Mexico:

$\begin{array}{lr}\text { Under } 5,000 & 28 \\ 5,000-10,000 & 14 \\ 10,000-30,000 & 9 \\ \text { Over } 30,000 & 4\end{array}$

Summary of Mississippi BAWI Plants, op. cit. supra note 5; Counties and Towns Using 1955 Bond Act, Tennessee Industrial and Agricultural Development Commission (Jan. 1961); The Arkansas Gazette, Jan. 15, 1961, \& F, p. 1f, col. 1; The Wall Street Journal, Oct. 11, 1960, p. 1, col. 1 .

49. Interview with Walter Harris, Acting Director of City Planning Studies, School of Art and Architecture, Yale University, Feb. 15, 1961.

50. See, e.g., Wickard v. Filburn, 317 U.S. 111 (1942); Village of Deming v. Hosdreg Co., 62 N.M. 18, 303 P.2d 920 (1956). 
Since alleviation of unemployment is frequently mentioned as a primary justification for industrial projects, it will serve as the focus for examining the kind of analysis required for judicial evaluation of the net gain to community values. In order to justify a project on this basis, there must be (1) unemployment, coupled with (2) a likelihood that the project will in fact put local people to work who are currently unemployed. ${ }^{51}$ The requirement that there be unemployment or, more generally, a need for new jobs, provides a measure of flexibility to the courts. The Tennessee supreme court in McConnell $v$. City of Lebanon ${ }^{52}$ found that the need for new jobs in 1958 justified municipal financing of new industry. A 1925 decision ${ }^{53}$ declaring such a plan unconstitutional was distinguished, partly on the ground that economic need was not demonstrated in the earlier decision. ${ }^{54}$ As a result of this approach, the courts in Tennessee are not bound to a rigid doctrine declaring all such projects a public purpose. The Tennessee court, through its use of personal income and population migration statistics, ${ }^{55}$ leaves room for an attack on the project on the basis of insufficient need.

Assessing the likelihood that a project will relieve unemployment involves a more difficult prediction of future events. Relevant to this determination would be such factors as (a) the relationship of the new jobs to the skills and potential skills of the local unemployed; (b) the prohibitions-both of cost and contract -on importing outside labor; and (c) the prospects that the plant will employ a significant number of workers over a long period of time at a satisfactory wage level.

51. See, e.g., Dycke v. City of London, 288 S.W.2d 648, 650 (Ky. 1956) :

The validity of a project of this type, which closely approaches public aid to private industrial interests, depends entirely upon the existence of underlying economic conditions which render the project essentially one of a "public" nature .... Since the record reveals that widespread unemployment exists in the City and its surrounding area, and shows that many citizens are in dire need of employment which they are more likely to obtain if new industry can be attracted to the area, we think the burden ... has been met.

It can be argued that such a finding was unnecessary in Wayland because the taxpayer conceded in his complaint the existence of widespread unemployment which would be alleviated by the project. $I d$. at 635 . In fact, Batesville was in a depressed area with $20 \%$ of the labor force unemployed and another 20\% working only part time. The Arkansas Department of Labor interviewed all the unemployed, underemployed, and unsatisfied workers to measure their skills and potential skills "on a scale never before attempted in a rural area." The availability of skilled workers was one reason Seiberling came to Batesville. The N.Y. Times, February 26, 1961, p. 1, col. 1. The Wayland court did not indicate what weight, if any, it attached to these facts in reaching its decision.

52. 203 Tenn. 498,314 S.W.2d 12 (1958).

53. Ferrell v. Doak, 152 Tenn. 88, 275 S.W. 29 (1925).

54. In a similar way the Mississippi Supreme Court in Albritton v. City of Winona, 181 Miss. 75, 178 So. 799 (1938), did not overrule but distinguished on its facts its earlier ruling in Carothers v. Town of Booneville, 169 Miss, 511, 153 So. 670 (1934), which had declared a municipal financing plan unconstitutional. The Albritton court found that economic and social justifications for Winona's project were absent from Booneville's plan. 181 Miss. at 109,178 So. at 809.

55. McConnell v. City of Lebanon, 203 Tenn. 498, 314 S.W.2d 12, 14 (1958). 
Hopefully, a court's focus on such factors as employment and migration statistics will lead to the development of some meaningful standards by which a project's economic consequences can be tested. Two states have made some effort toward achieving this goal. Statutes in Mississippi and Tennessee both require, prior to the approval of a municipal financing project, that there be one and one-half available workers in a twenty-five mile radius of the new plant for each operative job created. ${ }^{.6}$ Judicial consideration of these factors may also lead legislatures and challenging parties to formulate their conclusions about the need for and probable impact of such projects in more precise terms, ${ }^{57}$ so that courts evaluating individual projects may have a better basis of comparison and precedent than is presently attained through the random listing of statistics, ${ }^{58}$ and the reciting of phrases such as "abnormal," "widespread," or "crisis." 59

The number of values affected by industrial development approach infinity. Nevertheless an attempt to enumerate some of them may help to focus attention on the more relevant and intense value effects in each case. The following analysis draws in part upon the systematic analysis of community values made by Professors Lasswell and McDougal.60

Among the factors to be considered in determining the effect of a municipally financed project on a community's shared wealth are the aggregate income it will make available for community distribution, the resulting security or insecurity of income, and the opportunities for more lucrative employment for those who desire to work for it. Of concern, therefore, are projected employment and wage levels, and the stability of the employer. ${ }^{01}$ It would be

56. Mrss. Code Ann. \$ 8936-08(2) (1942); Tenn. Code Ann. \$ 6-2906(2) (Supp. (1960). To obtain a certificate of public convenience and necessity in Mississippi community officials must report the number of men and women between 18 and 50 years of age who are "available and willing to work in the proposed type of industrial enterprise." Mississippi Agricultural and Industrial Board, Attitude in Action. This does not, of course, indicate whether those willing to work are also sufficiently skilled to perform the tasks needed in the new enterprise, which is the particular merit of the government study in Batesville, note 51 supra.

57. For example, a comparison might be made between the project's cost per job and the cost of other projects. The Batesville project cost $\$ 10,000-15,000$ per job while Greenwood, Arkansas, issued $\$ 3750$ in bonds for each new job. See statistics quoted in Arkansas Gazette, Jan. 15, 1961, p. 1f, col. 6. For a presentation of techniques that can be used to estimate and evaluate the effects of a new industry on a locality, see ISARd, Methods of Regronal ANalYSis: An InTroductron to Regronal Science (1960).

58. See, $c . g$., the court's use of statistics in MrConnell v. City of Lebanon, 203 Tenn. 498, 314 S.W.2d 12, 14 (1958).

59. See Dyche v. City of London, 288 "S.W.2d 648, 650 (Ky. 1956); McConnell v. City of Lebanon, 203 Tenn. 498, 314 S.W.2d 12 (Tenn. 1958)."

60. Lasswell \& McDougal, The Jurisprudence of a Free Society: Studies in Law, Science Aind Policy (1954) (tent. draft).

61. Employer stability should not be lightly assumed, particularly in view of the tendency of the projects under discussion to attract relatively small businesses. Since 1957, of 154 industries making use of municipal financing projects in Tennessee and Mississippi, only 21 were listed in Moody's Industrials. See compilations cited note 33 supra. 
relevant to initiate or consult studies such as the United States Chamber of Commerce study which estimates that with each 100 new factory workers, aggregate personal income rises $\$ 590,000$ a year, actual new employment is 174 persons, retail sales increase $\$ 360,000$ annually and bank deposits rise $\$ 270,000 .^{62}$ Authoritative decision makers might also investigate the wisdom of attempting to secure stable income levels through the inclusion of provisions for guaranteed minimum wages in the lease agreement. ${ }^{63}$

The consequences of a project should be directed toward a maximization of general participation in decision making, a minimum of concentration and centralization of power, and an absence of coercion and exclusion from decision processes. A new industry may become a political Leviathan. ${ }^{64}$ For example, if the industry is free to "pull out" or "slow down" without incurring serious losses, it may use these sanctions to coerce community decisions or to exclude some, labor unions perhaps, from community decision making processes. Such situations may be more likely when (1) the industry has other plants capable of supplying the demands for goods if the new plant is closed; (2) the industry has insulated itself from breach of contract or lease liability by incorporating the new facility separate from its other holdings; (3) the industry's payroll, number of employees, or output is vital to the wealth, wellbeing, or other values of the community. On the other hand, larger corporations may tend to give more attention to political education of employees. ${ }^{65}$ Also, management in such corporations may be removed from the local scene, and may be less likely to interfere in local governmental affairs. Moreover, the multifactory employer may find it difficult not to extend the institution of collective bargaining to the new location, for the union in existing plants may exert considerable coercive pressure for organization.

Another relevant inquiry is the likelihood of employee participation in industrial decision. One motive for industrial relocation may be the manufacturer's desire to escape unionism. ${ }^{66}$ Those responsible for bringing in the new industry should consider whether the opportunity for employment without collective organization will ultimately further the interests of the local workers-not only in terms of wealth, but also with regard to the development of the worker

62. Chamber of Coamarerce of the United States, What New Industrial Jobs MeAN to a Coandunity (1960). The accuracy of the study may be questioned, however, due to factors such as the lack of a control group to show the development of communities not benefiting from new industrialization during the 1940-1950 period under consideration.

63. One court has expressed concern about uncontrolled wage levels and the stability and continuity of employment in determining public purpose, though the context of its discussion is not clear. Ferrell v. Doak, 152 Tenn. 88, 275 S.W. 29 (1925).

64. See, e.g., the conclusions in Hunter, Community Power Strucrure (1953); Lynd \& Lynd, Middletown in Transition (1937).

65. For a discussion of corporate political activities, see Comment, Corporate Political Affairs Pragrams, infra.

66. See Fortune, July, 1954, pp. 35, 38, 
as a participant in community decisions through the experience gained from participation in the institutions of collective bargaining. ${ }^{.7}$

The status of individuals in the community may be affected by the likelihood of discrimination in employment. Local officials should weigh the advisability of inserting "FEPC-type" conditions in their lease agreements with industry. Indeed, such provisions may be necessary, for discrimination by a municipally financed industry in its employment practices may violate the fourteenth amendment. Municipal financing abounds in "state action." The municipality holds title to the property. ${ }^{68}$ Municipal securities finance the project. Tax exemptions are granted the project because it is viewed as a municipal activity.

Among factors to be considered to determine the effect of a municipally financed project on shared well-being are (1) the safety precautions within the plant; (2) arrangement for disposing of industrial wastes; (3) impact of increased travel on roads and traffic conditions; (4) effect of added population on existing and projected sanitation and health, recreation, police and fire personnel and facilities; (5) availability of adequate housing for newcomers; (6) psychological tensions which the new industry creates or alleviates. ${ }^{60}$ The argument for finding a public purpose becomes weaker if, for example, no provisions have been made for increased traffic, housing needs, sewerage disposal or health requirements.

The impact of industrial development on educational facilities and communication media must be considered. The United States Chamber of Commerce estimates that the influx of 100 new factory workers will bring 51 more school children..$^{70}$ The advent of a corporate giant may augment the concentration of

67. For discussion of the relationship between individual moral responsibility and individual participation in the industrial decisions which affect him, see FROMIM, ESCAFE FROMI FrEeDOM 272-76 (1941). For a discussion of the moral necessity for individual as opposed to collective or authoritarian judgments, see Fluger, MAN, Morals and Soctery 252-53 (2d printing 1947).

It may be advisable, however, to guard against excessive union involvement in the project. See The Reporter, Feb. 2, 1961, p. 28 , describing the purchase of $\$ 3$ million of a $\$ 4.5$ million bond issue by the International Brotherhood of Teamsters, the subsequent representation contest between the Teamsters and the UAW, community pressures exerted in favor of the Teamsters, and allegations by the UAW that the Teamsters sought to depress working conditions to safeguard their investment.

68. See, e.g., Derrington v. Plummer, 240 F.2d 922 (5th Cir. 1956), cert. denied, 353 U.S. 927 (1957) (prohibiting discrimination in private lunchroom on premises leased from the city). But see Dorsey v. Stuyvesant Town Corp., 299 N.Y. 512, 87 N.E.2d 541 (1949), cert. denied, 339 U.S. 981 (1950) (discrimination allowed in housing project built with aid of city condemnation and 25 year tax exemption; premises owned by private developer).

69. To the extent that new industry comes from northern industrial areas, it may bring with it behavior and attitudes which clash with the predominantly southern and rural areas in which these projects seem to be flourishing.

70. Chamber of Commerce of the United States, op. cit. supra note 61. On the impact of industrialization on general education, see generally, Counts, Secondary Education and InDUSTRIALISM (1929). 
control of local communication media by business and industrial interests. On the other hand, industrialization may increase the tax base available for school budgets, and more wealth and employment may afford more individuals greater access to sources of information. ${ }^{71}$ The crime rate, divorce rate, church attendance, religious and ethical beliefs and practices generally, may also be affected by industrialization. ${ }^{2}$

71. See generally, Chinds \& Cates, Ethics in a Business Soctety (1954); Moody, Church and Soctety (1935). 